\title{
Gerakan Dialog Keagamaan Jaringan Kerja Antar Umat Beragama (Jakatarub) Dan Kontribusinya Terhadap Kerukunan Hidup Umat Beragama
}

\author{
Dwi Wahyuni \\ UIN Sunan Gunung Djati Bandung, Indonesia \\ Email: wahyunid27@gmail.com
}

\begin{abstract}
A study of the religious dialogue movement Interfaith Network (JAKATARUB) and its contribution to the harmony of life in religious communities in the city of Bandung. The purpose of this study is to explain the strategies and tactics of the JAKATARUB religious dialogue activist, analyze the supporting and inhibiting factors of the JAKATARUB religious dialogue movement and determine the contribution of the JAKATARUB religious dialogue movement to the harmony of religious life in the city of Bandung. Using qualitative methods, the data collection techniques are observation, interviews, documentation and literature study. The theoretical framework used is resource mobilization theory and framing process theory. JAKATARUB in its religious dialogue movement is expanding networks, mobilizing resources and changing organizational structures. The next strategy is JAKATARUB, down to the small parts of each step of the movement. These sections are the implementation of programs in collaboration with JAKATARUB partners and convey the meaning of the priority issues of the movement to the target group. The implementation of programs and the delivery of meaning are tactics of the JAKATARUB religious dialogue movement.
\end{abstract}

Keywords: Movement, Harmony, Religious People

\begin{abstract}
ABSTRAK
Penelitian mengenai gerakan dialog keagamaan Jaringan Kerja Antar Umat Beragama (JAKATARUB) dan kontribusinya terhadap kerukunan hidup umat beragama di Kota Bandung. Tujuan dari penelitian ini untuk menjelaskan strategi dan taktik yang dilakukan aktivis gerakan dialog keagamaan JAKATARUB, menganalisis faktor-faktor pendukung dan penghambat gerakan dialog keagamaan JAKATARUB dan mengetahui kontribusi gerakan dialog keagamaan JAKATARUB terhadap kerukunan hidup umat beragama di Kota Bandung. Menggunakan metode kualitatif, dengan teknik pengumpulan data secara observasi, wawancara, dokumentasi dan studi kepustakaan. Kerangka teori yang digunakan adalah teori mobilisasi sumberdaya dan teori proses framing. JAKATARUB dalam gerakan dialog keagamaannya ialah memperluas jaringan, mobilisasi sumberdaya dan merubah struktur organisasi. Selanjutnya strategi JAKATARUB, diturunkan kepada bagian-bagian kecil dari setiap langkah gerakan. Bagian-bagian tersebut ialah pelaksanaan program-program yang bekerja sama dengan mitra JAKATARUB dan menyampaikan makna dari isu-isu prioritas gerakan kepada kelompok sasaran. Pada pelaksanaan program-program dan penyampaian makna merupakan taktik dari gerakan dialog keagamaan JAKATARUB.
\end{abstract}

Kata kunci: Gerakan, Kerukunan,Umat Beragama

\section{PENDAHULUAN}

Arus ubanisasi di kota-kota besar Indonesia telah memberi pengaruh besar terhadap perubahan sosial. Termasuk juga di Kota Bandung, urbanisasi telah menjadikan wilayah ini sangat heterogen baik suku, budaya, agama bahkan berbagai aliran kepercayaan. Berbagai suku bangsa yang ada di Kota Bandung seperti Batak, Minahasa, Minangkabau, Ambon, Cina, Jawa dan suku dominan yakni Sunda. Berbagai agama yang secara resmi diakui pemerintah Indonesia seperti Islam, Kristen, Katolik, Hindu,

\footnotetext{
* Dwi Wahyuni

Received: Desember 05, 2019; Revised: Desember 10, 2019; Accepted: Desember 25, 2019
} 
Budha dan Konghucu, begitu juga berbagai keyakinan seperti Ahmadiyah dan Baha'i. Keberagaman ini di satu sisi dapat menjadi potensi yang dapat menambah daya tarik Kota Bandung, namun di sisi lain juga dapat menjadi potensi konflik.

Pluralitas agama dan keyakinan sebagai salah satu sumber konflik ditunjukkan oleh jumlah pengaduan pelanggaran hak atas Kebebasan Beragama dan Berkeyakinan (KBB) yang diterima KOMNAS HAM pada Januari-Desember 2016 berjumlah 97 pengaduan. Dari jumlah pengaduan tersebut, Jawa Barat menjadi daerah dengan jumlah pengaduan tertinggi sebanyak 21 pengaduan. Di Kota Bandung sendiri tercatat berbagai kebijakan yang diskriminatif terhadap warga Jaringan Ahmadiyah Indonesia. Permasalahan perijinan pembangunan gereja GBKP Bandung Timur, gereja GBKP Bandung Barat, gereja Rehoboth, gereja BNKP Nias, gereja Masehi Advent Hari Ke-Tujuh, dan gereja Kerajaan Mulia. Pembubaran kegiatan Kebaktian Kebangunan Rohani (KKR) umat Kristen di gedung Sabuga jalan Tamansari pada 6 Desember 2016.(Hemawati, 2016)

Dalam laporan tahunan kehidupan keberagamaan tahun 2016, indeks kerukunan hidup umat beragama di Provinsi Jawa Barat berada pada angkat 63,39\% dibawah indeks kerukunan nasional yakni 67,65\%. Angka indeks kerukunan ini diperoleh dari hasil pengukuran 3 (tiga) indikator yaitu: toleransi, kesetaraan dan kerjasama. Peningkatan kerukunan umat beragama, orientasinya tidak hanya pada aspek toleransi semata karena sikap toleransi itu baru merupakan syarat awal agar kerukunan umat beragama tumbuh semakin kuat, maka toleransi harus disertai dengan adanya sikap kesetaraan. Sikap kesetaraan juga harus diiringi tindakan nyata dalam berkerjasama di tengah masyarakat majemuk.(Wahyuni, 2016)

Berbeda dengan penelitian Rina Hermawati dkk, indeks toleransi Kota Bandung menunjukkan kategori "tinggi", yakni berada pada angka 3,82. Ini mengindikasikan bahwa interaksi sosial antarumat beragama di Kota Bandung telah berlangsung secara baik dan berada dalam batas-batas jarak sosial yang wajar.(Hemawati, 2016) Capaian ini menunjukkan bahwa persepsi, sikap, dan kerja sama dalam interaksi sosial antarumat beragama di Kota Bandung sudah berlangsung secara kondusif. Jarak sosial yang ada masih tergolong wajar karena kecenderungan penolakan terhadap pemeluk agama berbeda hanya berkaitan dengan ranah yang sangat pribadi atau berkaitan dengan identitas in-group dari suatu pemeluk agama. Dalam hal interaksi sosial lainnya, ada keterbukaan untuk menerima dan bergaul dengan pemeluk agama yang berbeda.

Perbedaan temuan di atas perlu disikapi dengan bijak, bukan dengan mempersoalkan keabsahan temuan yang dihasilkan, tapi dengan memaknai temuan tersebut sebagai indikasi bahwa masih terdapat potensi konflik dalam hubungan antar umat beragama di Kota Bandung. Berbagai studi yang dipaparkan di atas menunjukkan bahwa kerukunan umat beragama, termasuk sikap toleransi yang menjadi indikator dari kerukunan tersebut, masih menjadi persoalan bagi Kota Bandung. Walaupun dengan data yang ditunjukkan oleh penelitian Rina Hermawati dkk yang menilai positif indeks toleransi Kota Bandung. Meskipun demikian, mengingat beragam persoalan kerukunan hidup umat beragama ini tetap perlu ditangani agar potensi konflik yang mungkin muncul dapat dicegah.

Masyarakat dan pemerintah Kota Bandung harus mengatur dan mencari solusi agar tercipta kedamaian pasca konflik dan membangun kedamaian dan menyadari perbedaan sebelum terjadinya konflik.(Farida, 2015) Oleh karena itu, seluruh komponen masyarakat Kota Bandung dituntut untuk mencari titik-titik tertentu yang memungkinkan adanya titik temu atau paling tidak kebersamaan, sehingga terbuka peluang untuk tumbuhnya sikap toleran dalam menyikapi pluralitas Kota Bandung. Dalam kondisi objektif inilah dialog antar umat beragama diperlukan.(Febriani, 2017)

Secara historis gerakan dialog keagamaan di Indonesia dilatarbelakangi oleh peristiwa Meulaboh Pada Juli 1967. Sebuah gereja di Meulaboh Aceh Barat dibakar oleh penduduk muslim setempat. Peristiwa 
Khazanah Sosial, Vol. 1 No. 1: 50-60

Gerakan Dialog Keagamaan Jaringan Kerja Antar Umat Beragama (Jakatarub) Dan Kontribusinya Terhadap

Kerukunan Hidup Umat Beragama

Dwi Wahyuni

ini terjadi karena pembangunan gereja tersebut diyakini didukung penduduk keturunan Tiongkoa yang baru memeluk agama Kristen. Kemarahan kaum muslimin dipicu oleh kenyataan bahwa gereja tersebut dibangun di tengah pemukiman muslimin yang hanya dihuni oleh sejumlah kecil umat Kristiani. Peristiwa konflik juga terjadi di Makasar Sulawesi Selatan, pada 1 Oktober 1967, beberapa pemuda muslim merusak sekitar 20 gereja dan sekolah Katolik dan Protestan, serta membakar puluhan Injil, peristiwa ini dianggap dipicu oleh seorang guru Protestan yang membuat pernyataan yang menghina agama dan umat Islam.(Umar, 2013)

Menanggapi peristiwa konflik di atas KAMI (Komite Aksi Mahasiswa Indonesia), mengirim surat terbuka kepada pejabat Presiden Soeharto agar menghentikan konflik tersebut dengan cara membentuk sebuah lembaga kosultasi untuk mendiskusikan toleransi antar umat beragama. Atas tuntutan tersebut, Menteri Agama K.H Mohammad Dachlan melaksanakan Musyawarah Antarumat Beragama pada tanggal 30 November 1967 di gedung Dewan Pertimbangan Agung Jakarta. Dihadiri oleh sekitar 20 tokoh Muslim, Protestan dan Katolik. Diadakannya Musyawarah Antaraumat beragama tersebut karena pada saat itu timbul berbagai ketegangan antar berbagai agama di Indonesia, terutama antara Islam dan Kristen/Katolik, yang jika tidak segera diatasi akan dapat membahayakan persatuan dan kesatuan bangsa Indonesia.

Dialog antarumat beragama pada masa Orde Baru dilakukan dengan mengeluarkan berbagai kebijakan yang bertujuan untuk mengontrol kehidupan umat beragama. Hal ini dilakukan agar umat beragama tidak terlibat secara politis dan tidak terlibat konflik yang dapat menggoyangkan kekuasaan Orde Baru. Kebijakan pemerintahan Orde Baru terhadap dialog antarumat beragama juga sebagai usaha untuk mendapatkan dukungan dari para pemuka agama. Pemerintahan Orde Baru kurang tertarik untuk mengupayakan suasana dialog antarumat beragama yang didasarkan pada penyebaran nilai-nilai keadilan secara serius dan berkesinambungan.

Karena itu, sebagai suatu gerakan yang merespon konsep dan praktek dialog antarumat beragama yang diperkasai oleh pemerintah, beberapa lembaga non pemerintah mengambil insisatif untuk dialog antarumat beragama. Gerakan dialog keagamaan yang dilakukan sebenarnya merupakan respon kritis atas keyakinan bahwa upaya yang telah dilakukan pemerintah selama ini mengalami kegagalan. Sehingga diperlukan pendekatan yang berbeda dalam memahami dialog antarumat beragama. Salah satu kelompok yang konsentrasi terhadap dialog keagamaan ialah Jaringan Kerja Antar Umat Beragama (JAKATARUB) Kota Bandung.

JAKATARUB didirikan bermula dari serangkaian workshop tentang keberagaman dan toleransi yang diadakan Institute for Culture and Religion Studies (INCReS) dan Masyarakat Dialog Antar Agama (MADIA) pada 10-12 November 2000 di Pesantren Al-Wasilah, Garut. Selanjutnya workshop dilaksanakan kembali pada 20-22 April 2001 di Vihara Vipassana Graha, Lembang. Rangkaian workshop ini muncul atas niatan para tokoh agama serta budayawan nasional dari Jawa Barat yang disokong oleh alm. K.H. Abdurrahman Wahid (Gus Dur). Tujuan diadakannya workshop adalah demi mendorong kerukunan agama dalam konteks pengenalan yang mendalam sekaligus kerja sama yang strategis. Workshop ini dihadiri oleh sejumlah pemimpin agama dan kaum muda dari berbagai komunitas keagamaan di Jawa Barat.

Para peserta workshop kemudian bersepakat untuk membentuk suatu jaringan kerja antar umat beragama. sehingga pada 12 Mei hingga 30 Juni 2001 diadakan beberapa kali pertemuan berkala yang difasilitasi Gereja Katolik Hati Tak Bernoda Santa Perawan Maria, Bandung untuk mendiskusikan pendirian jaringan tersebut. Pada pertemuan ketiga tersebut mulai dibicarakan tentang format atau 
wadah demi keberlangsungan kerja transformatif dialog antaragama, yang kemudian menjadi cikal bakal lahirnya JAKATARUB.

JAKATARUB merupakan sebuah nama yang di dalamnya bersemayam 'nilai' semangat yang selalu ingin berbuat. Sebuah nama yang ingin menebus harapan dan cita-cita kedamaian umat manusia dengan kesungguhan untuk melakukan sesuatu. Sebuah ikhtiar yang diidealisasikan untuk membawa kehidupan beragama ke arah yang lebih terbuka, santun, beradab, dan mampu turut menciptakan kedamaian sosial, keadilan manusia, dan kebersamaan dalam keragaman.

JAKATARUB bersifat independen, tidak berafiliasi dengan partai poltik atau ada di bawah lembaga lainnya. JAKATARUB bertujuan untuk menghadirkan toleransi dan kerukunan antar umat beragama dengan pengenalan yang mendalam antar satu sama lain. Jaringan ini menekankan pergerakannya pada bidang budaya dan penguatan kesadaran masyarakat. Sejak tahun 2014 JAKATARUB memusatkan semua aktivitas dan programnya pada empat tema, yaitu: Diskusi teologis, Elaborasi Seni dan Budaya, Kampanye Media dan Pengayaan Konsep dan Wawasan Kebangsaan. Keempat tema ini bertujuan untuk memperluas serta memperdalam pemaknaan toleransi di berbagai segmen masyarakat dengan melibatkan banyak komunitas dan invididu dalam mengerjakannya. Saat ini JAKATARUB telah bermitra aktif dengan 10 Lembaga Keagamaan, 11 Lembaga/komunitas kebudayaan dan beberapa lembaga swadaya masyarakat serta lembaga pendidikan.

Namun demikian, masih terdapat beberapa permasalahan terkait gerakan dialog keagamaan yang dilaksanakan oleh JAKATARUB ini. Terutama bagaimana menjelaskan gerakan dialog keagamaan JAKATARUB dalam prespektif teori gerakan sosial. Strategi dan taktik seperti apa yang dilakukan aktivis gerakan dialog keagamaan JAKATARUB untuk menggapai tujuannya. Serta faktor-faktor apa yang menghambat dan mendukung gerakan dialog keagamaan yang dilakukan oleh JAKATARUB. Untuk menjawab pertanyaan-pertanyaan ini, penulis akan menganalisis gerakan dialog keagamaan JAKATARUB menggunakan dua teori yakni teori mobilisasi sumberdaya dan teori proses framing.

Teori mobilisasi sumberdaya digunakan untuk memahami basis rasionalitas gerakan dialog keagamaan yang dilakukan oleh JAKATARUB. Teori mobilisasi sumberdaya juga digunakan untuk melihat bagaimana JAKATARUB memobilisasi sumberdaya yang mereka miliki. Sedangkan teori proses framing digunakan untuk memahami bagaimana para aktor gerakan dialog keagamaan JAKATARUB Kota Bandung dalam membingkai isu-isu seperti toleransi, kebebasan beragama, demokrasi dan perdamaian. Sejauh mana isu-isu tersebut disampaikan dalam bahasa yang mudah dipahami oleh masyarakat atau kelompok sasaran.

\section{METODE PENELITIAN}

Penyajian data dilakukan setelah peneliti selesai melakukan reduksi pada seluruh data yang diperoleh.(Silalahi, 2010) Data yang telah ada sesuai dengan instrumen penelitian kemudian peneliti narasikan sesuai dengan data. Selanjutnya dideskripsikan secara spesifik mengenai fokus masalah dari penelitian. Penyajian data dilakukan dengan menggambarkan data secara tersusun dan menarik kesimpulan dalam bentuk teks naratif. Dalam penelitian kualitatif (Sugiyono, 2013), teknik analisis data lebih banyak dilakukan bersamaan dengan pengumpulan data. Menganalisis data kualitatif dilakukan secara interaktif melalui proses: Data Reduction, Data Display, dan Verification.(Sukmana, 2016)

\section{HASIL DAN PEMBAHASAN}


Khazanah Sosial, Vol. 1 No. 1: 50-60

Gerakan Dialog Keagamaan Jaringan Kerja Antar Umat Beragama (Jakatarub) Dan Kontribusinya Terhadap

Kerukunan Hidup Umat Beragama

Dwi Wahyuni

Faktor pertama yang mendukung gerakan JAKATARUB ialah regenerasi, dari awal berdiri sampai saat ini sudah terjadi tiga generasi di JAKATARUB secara terus-menerus berganti. Faktor kedua, jaringan JAKATARUB yang luas juga menjadi pendukung. Kerjasama dengan mitra-mitra membuat JAKATARUB lebih banyak ruang geraknya dalam upaya melakukan dialog keagamaan. Faktor ketiga, di JAKATARUB diterapkannya sistem kekerabatan yang cair, sehingga membuat para anggotanya nyaman dan bebas mengutarakan apa yang menjadi keresahan mereka tanpa harus takut ada tekanan dari pihak lain. Hal ini menimbulkan rasa kepemilikkan bersama atas JAKATARUB. Faktor keempat, saat ini telah banyak komunitas maupun organisasi yang berbicara tentang toleransi sehingga telah timbul keterbukaan masyarakat terhadap dialog keagamaan. Berikut penjelasan tentang faktor-faktor pendukung gerakan dialog keagamaan JAKATARUB:

\section{Regenerasi Anggota dan Pengurus}

Dalam menjalankan roda kepengurusan JAKATARUB memiliki sistem rekrutmen anggota dengan cara yang alami dan terbuka, sehingga banyak dari anggota JAKATARUB yang berasal dari bermacammacam kalangan, latar belakang, agama dan keyakinan. Khusus untuk pengurus harian, sebenarnya tidak ada sistem baku, biasanya yang menjadi pengurus harian ialahanggota-anggota yang pernah mengikuti perkemahan lintas agama.

Komunitas pada dasarnya digunakan sebagai wadah atau tempat untuk orang-orang berkumpul secara rasional, terpimpin dan terkendali untuk mencapai tujuan bersama. Seperti halnya JAKATARUB yang telah mengalami tiga generasi dari awal berdiri sampai saat ini. Selalu ada generasi muda yang merasa bahwa gerakan dialog keagamaan itu penting. Ada banyak anak muda yang memang serius bergabung di gerakan ini sebagai relawan. Anak-anak muda dengan tenaga dan semangat yang masih bagus untuk membantu kegiatan yang ada di JAKATARUB. Seperti generasi Risdo kebawah itu sangat bagus sekali.

Selalu ada generasi baru yang serius untuk berkontribusi di JAKATARUB merupakan faktor penting yang mendukung gerakan dialog keagamaan JAKATARUB. Keanggotaan JAKATARUB sendiri dapat dipetakan dalam tiga lingkaran, lingkaran pertama lingkaran keluarga besar, ini orang-orang yang sering mengikuti kegiatan JAKATARUB kisaran anggotan 100-200 orang. Lingkaran kedua adalah lingkaran yang lebih intens yakni orang-orang yang memiliki historis dan ikatan kerja sama dengan JAKATARUB. Meraka disebut sebagai sportif team yang sering dilibatkan dalam event-event rutin dan kegiatan-kegiatan penting. Dan yang terakhir, lingkaran inti yakni pengurus hariannya, untuk pengurus harian sendiri sekitar belasan orang.

\section{Jaringan yang Luas}

Selain regenerasi, jaringan juga merupakan faktor pendukung dalam gerakan dialog keagamaan JAKATARUB. Untuk mencapai tujuannya JAKATARUB tetap berkerjasama dengan beberapa komunitas atau organisasi lainnya. Menurut Wawan Gunawan, JAKATARUB telah berjejaring dengan banyak lembaga dan itu sangat luar biasa seperti Askara, Yayasan Rahmatan Lilalamin. LBH Bandung, Sapa Institute, Institute Perempuan, Fatayat NU. Kerjasama dengan mitra-mitra yang telah terjalin inilah membuat gerakan JAKATARUB semakin bagus.

JAKATARUB telah bermitra aktif dengan Lembaga Keagamaan, Lembaga atau komunitas kebudayaan dan beberapa lembaga swadaya masyarakat serta lembaga pendidikan. Sejak tahun 2014, JAKATARUB telah berkerja sama dengan mitra aktif yang terdiri dari lembaga keagamaan seperti: PCNU Bandung, Sinode Gereja Kristen Pasundan (GKP), Gereja Kristen Indonesia (GKI) Kebonjati, Majelis Agama Konghucu Indonesia (MAKIN) Bandung, Jama'ah Ahmadiyah (JAI) Indonesia Wilayah Priangan Barat, Komisi Hubungan Antar Kepercayaan dan Komisi Kerasulan Awam Keuskupan Bandung, Paroki St. 
Khazanah Sosial, Vol. 1 No. 1: 50-60

Gerakan Dialog Keagamaan Jaringan Kerja Antar Umat Beragama (Jakatarub) Dan Kontribusinya Terhadap Kerukunan Hidup Umat Beragama

Dwi Wahyuni

Laurentius, Gereja Katerdral St. Petrus Bandung, Paroki St. Mikael, JAI Bandung, Mayarakat Baha'i Bandung, Komunita Budidaya, Vihara Dharma Rhamzy, Vihara Tanda Bhakti dan Tao Kwan Sinar Mulia.

Lembaga atau komunitas kebudayaan Layar Kita, Museum Konferensi Asia-Afrika (MKAA) dan Aliansi Bandung Lautan Damai (BALAD). Lembaga swadaya masyarakat seperti Dian/Interfidei (Institute for Interfaith Dialogue in Indonesia), KOMNAS Perempuan, SAPA Institute, Forum Lintas Agama Deklarasi Sancang (FLADS), Lembaga Bantuan Hukum (LBH) Bandung, Peace Generation, dan Jaringan Gusdurian. Dan juga lembaga pendidikan seperti Universitas Kristen Maranatha, BEM Universitas Islam Bandung (UNISBA), UIN Sunan Gunung Djati Bandung, Universitas Parayangan, FISIP Universitas Padjajaran dan Telkom University.

\section{Sikap Kekerabatan dan Rasa Memiliki}

Setiap pengurus dan anggota JAKATARUB memiliki sifat kekerabatan yang sangat baik, yang telah menjadi ciri khas dari JAKATARUB itu sendiri. Selain itu, di JAKATARUB juga ditanamkan rasa kepemilikan bersama atas JAKATARUB. Sehingga setiap anggota merasa nyaman dan inggi berkontribusi lebih dalam setiap kegiatan-kegiatan JAKATARUB. Seperti hasil wawancara yang disampaikan Risdo tentang sikap kekerabatan dan rasa memiliki di JAKATARUB:

"Secara internal yang mendukung ialah sifat kekerabatan di JAKATARUB. Kita sifatnya sangat sukarelawan dan sangat percaya bahwa kita tidak ada niatan apa-apa, karena kita tidak dapat apaapa dari JAKATARUB, tidak mendapatkan keuntungan materi finacial dari kegiatan-kegiatan. Semua orang mempunyai kerjaanya masing-masing, hanya mereka konsen disini, dan jadi di satu sisi sikap kekerabatan yang sangat besar, banyak orang yang selau ada saja setiap bulam setiap tahun pasti bergabung di JAKATARUB. Jarang ada gerakan toleransi yang bisa dapat tempat seperti JAKATARUB, di JAKATARUB banyak orang dengan senang hati masuk dan bergabung bersumbangsih. Itu menjadi satu yang sangat mendukung sampai saat ini dan itulah yang membuat JAKATARUB sampai saat ini masih bertahan karena merasa kekerabatan dan kepemilikan bersama, erasa memiliki JAKATARUB"

\section{Keterbukaan Masyarakat}

Saat ini telah banyak berbagai komunitas, organisasi bahkan dari pemerintah juga yang berbicara akan pentingnya toleransi. Hal ini menjadi pendukung juga dalam gerakan dialog keagamaan JAKATARUB. Banyaknya yang bergerak dibidang ini menimbulkan keterbukaan masyarakat. Dengan lebih terbukanya masyarakat terhadap isu-isu toleransi, perdamaain dan sebagainya. Memberikan peluang bagi gerakan dialog keagamaan dalam ruang yang lebih luas lagi. Berikut wawancara dengan risdo terkait hal ini:

"Dari sisi eksternalnya dalam konteks Indonesia sekarang, tentu Pemerintah sangat mempromosikan isu-isu tentang keberagaman. Jadi ada banyak dana dan sumberdaya untuk mengelola isu ini di Indonesia. Walaupun kadang-kadang jatuh di tangan yang kurang tepat, atau kadang-kandang dijadikan sebagai alat kampanye politik juga. Sekarang banyak membicarakan tentang toleransi bahkan kepada orang-orang yang belum dikenal dan tidak pernah bicara soal toleransi menjadi bicara soal toleransi. Hal ini berdampak keterbukaan masyarakat yang lebih luas. Keterbukaan masyarakat ini, saya rasa menjadi faktor pendukung. Secara khusus juga untuk konteksnya Bandung, memang kulturnya kita lebih kreatif, legaliter dan kecendrungan untuk belajar itu cukup besar. Ternyata ada di generasi muda, beberapa kali kita buat event Cafe Religi, mahasiswa dan anak-anak muda kita undang. Pembicara dari agama-agama yang mereka jarang temui seperti Khonghucu, Tao atau Buddha. Mereka sangat antusias untuk bertanya lebih jauh, mungkin awalnya sama sekali tidak tahu tapi ternyata akhirnya tergerak untuk mencari tahu. Jadi ada kecendrungan kesana yang lebih besar saya kira, itu menjadi peluang yang cukup baik walaupun disisi lain banyak tantangannya juga". 
Khazanah Sosial, Vol. 1 No. 1: 50-60

Gerakan Dialog Keagamaan Jaringan Kerja Antar Umat Beragama (Jakatarub) Dan Kontribusinya Terhadap

Kerukunan Hidup Umat Beragama

Dwi Wahyuni

Beberapa faktor yang menjadi pendukung dalam gerakan dialog keagamaan JAKATARUB telah dipaparkan. Selanjutnya dipaparkan faktor penghambat gerakan dialog keagamaan JAKATARUB. Faktor pertama yang menghambat gerakan JAKATARUB ialah respon negatif dari eksternal. Kedua, prasangka sebagian mitra atau anggota JAKATARUB terhadap kelompok tertentu, seperti Ateisme, Ahmadiyah dan Syiah. Faktor ketiga yang menghambat gerakan JAKATARUB ialah keuangan dan sumberdaya manusia. Berikut penjelasan tentang faktor-faktor penghambat gerakan dialog keagamaan JAKATARUB:

\section{Respon Negatif dari Eksternal}

Faktor pertama yang menjadi penghambat dalam gerakan dialog keagamaan JAKATARUB berasal dari eksternal. Beberapa anggota dari lembaga atau organisasi keagamaan merespon negatif terhadap keberadaan JAKATARUB. Respon negatif ini sebenarnya berawal dari salah paham terkait pandangan JAKATARUB terhadap kelompok kenyakinan seperti Ahmadiyah, Syiah dan lainnya. JAKATARUB yang dianggap terlalu bebas dan mendukung keberadaan kelompok kenyakinan yang dipandang sebagai aliran sesat. Padahal, yang dilakukan JAKATARUB sendiri ialah usaha membela kelompok yang diperlakukan tidak adil di Indonesia. Bagi JAKATARUB, kelompok kenyakian seperti Ahmadiyah juga merupakan warga negara Indonesia dan berhak hidup dengan aman di Negara Indonesia. Pembelaan JAKATARUB terhadap Ahmadiyah inilah yang membuat beberapa anggota lembaga dan organisasi keagamaan merespon negatif keberadaan JAKATARUB.

Respond negatif terhadap keberadaan JAKATARUB bukanlah dilakukan oleh lembaganya melainkan oleh personal dari lembaga tersebut. Seperti halnya di FKUB Kota Bandung, bukan FKUB yang berpandangan negatif dengan JAKATARUB, namun ada satu dua anggota FKUB yang berpandangan negatif terhadap JAKATARUB. Hal ini terjadi karena perbedaan pandangan antar individu tersebut dengan JAKATARUB terkait kelompok kenyakinan seperti Ahmadiyah, Syiah dan lainnya. Berikut wawancara dengan Wawan Gunawan terkait dengan hal ini:

"Respon itu sendiri terbagi menjadi dua ya, ada yang merespon baik seperti Pak Dadang dari KESBANG tapi ada juga yang salah paham atau merespon kurang baik. Kenapa bisa kurang baik karena Jakatarub JAKATARUB itu mengakomodir kelompok-kelompok yang tidak biasa diterima oleh Pemerintah, seperti kelompok Syiah, Ahmadiah, dan Baha'i. Pemerintah mempunyai referensi bahwa agama itu ada enam, Islam, Kristen Katolik, Kristen Prostestan, Buddha, Hindu dan Khonghucu. Karena di JAKATARUB merangkul semua itu bukan saja enam agama bahkan lebih. Inilah yang membuat JAKATARUB dipandang Pemerintah sebagai gerakan yang liar, bebas dan sesat".

Akomodir JAKATARUB terhadap kelompok agama atau kenyakinan yang tidak diakui Pemerintah Indonesia ini memiliki dampak negatif terhadap JAKATARUB sendiri. Dampak negatif utama ialah pada relasi JAKATARUB dengan lembaga keagamaan formal seperti MUI, FKUB dan lainnya. Relasi baik antara JAKATARUB dengan lembaga-lembaga tersebut hanya pada diri personal dari kedua pihak saja, namun secara organisatoris, relasi itu tidak berjalan dengan baik. Karena itu, dalam kepengurusaan JAKATARUB perlu ada bidang yang fokus secara konstinue guna membangun dan menjaga komunikasi dengan berbagai lembaga keagamaan formal dan juga pemerintah Kota Bandung. Bidang ini mesti merancang dan melaksanakan strategi agar JAKATARUB dapat diterima sepenuhnya oleh lembaga keagamaan formal dan pemerintah Kota Bandung.

\section{Prasangka Terhadap Kelompok Tertentu}

Tidak semua mitra dan anggota JAKATARUB memandang baik kepada Ateisme dan kelompok keyakinan sepeti Ahmadiyah dan Syiah. Prasangka terhadap kelompok ini menjadi hambatan sendiri bagi gerakan dialog keagamaan JAKATARUB. Bila ada kegiatan yang bertemakan tentang Ateisme misalkan, ada beberapa gereja yang menolak. Begitu juga bila ada kegiatan yang dilaksanakan di tempat ibadah, dan 
Khazanah Sosial, Vol. 1 No. 1: 50-60

Gerakan Dialog Keagamaan Jaringan Kerja Antar Umat Beragama (Jakatarub) Dan Kontribusinya Terhadap

Kerukunan Hidup Umat Beragama

Dwi Wahyuni

saat itu hadir dari Ahmadiyah, tuan rumah kegiatan merasa tidak nyaman atau takut untuk menunjukkan kalau Ahmadiyah hadir dalam kegiatan tersebut. Hal ini terungkapkan saat wawancara dengan Sonny Herman, berikut hasil wawancaranya:

"Yang menjadi kendala itu kadang-kadang penghargaan terhadap yang lain itu masih terukur, maksudnya gak full 100 persen. Misalnya begini, contoh, ketika mau mengadakan acara dengan tema Ateisme, itukan tempatnya sulit sekali. Bahkan saya pernah beberapa kali ada acara, tapi ada permintaan: "nanti jangan ada orang Ateis yang datang". Akhirnya saya, Yunita dan Kang Wawan harus putar otak, gimana ini. sehingga waktu itu, iya udah jangan ditulis organisasinya, namanya saja. Nanti bilang sama orang Ateis tidak usah ditulis, kalau yang lain ditulis. Kendala lain Ahmadiyah, kalau acara di gereja, berapa kali gereja ketakutan untuk mengundang Ahmadiyah. Gereja Kebonjati itu mengalami, ketika mereka sebutkan Warta Jemaatnya menyebutkan Ahmadiyah, itu diprotes oleh Majelis. "Jangan ditulis ini, kalau kertas ini ketahuan di luar, itu kita bisa jadi kena". Terus waktu di gereja saya di Mikael, pernah buka puasa bersama, saat itu Romo Alex memanggil saya secara pribadi. "Ini gimana pembukaan, saya mau sebutkan undangan yang hadir, Ahmadiyah disebutkan atau tidak". 15 menit lebih kami berdebat, saya, Yunita dengan Romo Alex soal Ahmadiyah. Ahmadiyah dan Syiah kami ketakutan. Kenapa bisa begitu, karena kita tidak bisa lepas dari masyarakat, jadi kita tidak bisa lepas dari prasangka. Gak semuannya orang JAKATARUB, apalagi waktu itu masih baru, saya juga masih baru, banyak orang kenalan-kenalan baru, itukan masih banyak prasangka dalam kepalanya masing masing. Soal Ateisme, soal Ahmadiyah dan soal Syiah, itu masih punya prasangka".

\section{Keuangan dan Sumberdaya Manusia}

Selain dua faktor di atas, faktor yang menghambat dalam dialog keagaman JAKATARUB ialah keuangan dan sumberdaya manusia. JAKATARUB merupaka komunitas yang tidak mengelolah dana tetap. Karena itu, keuangan di JAKATARUB selalu tidak stabil dan juga tidak bisa membebakan kepada anggota. Sehingga pengurus inti memang berpikir keras di awal tahun untuk dapat membiayai programprogram JAKATARUB. Sebelumnya yang menjadi kendala dalam kepengurusan JAKATARUB ialah tempat untuk rapat dan sebagainya. Dan sekarang JAKATARUB sudah memiliki sekretariat, namun timbul kendala baru yakni bagaimana untuk membiayai dana operasional sekretariat tersebut.

Selain masalah keuangan, yang menjadi penghambat juga ialah masalah sumberdaya manusia. Di JAKATARUB sendiri tidak ada yang bisa full time fokus dengan JAKATARUB. Baik anggota maupun pengurus, semuanya telah memiliki perkerjaan sendiri-sendiri. Sebenarnya hampir setiap tahun JAKATARUB melaksanakan Youth Interfaith Camp sebagai kegiatan kaderisasi untuk merekrut anggota baru dengan mengundang mahasiswa di berbagai kampus. Lalu setelah selesai Youth Interfaith Camp, beberapa peserta yang kelihatannya tertarik diajak untuk bergabung di pengurusan dan dilibatkan dalam kegiatan-kegiatan. Namun karena sebagian besar kondisi kuliah mereka, lama kelamaan mereka sudah tidak aktif lagi. Sehingga regenerasi diJAKATARUB dari satu tahun itu paling bertahan satu atau dua orang. Berikut wawancara dengan Risdo terkait dengan hal ini:

"Sumberdaya yang tidak mencukupi, kadang banyak sekali tawaran dan harapan sebenarnya sangat baik. Tapi kita tidak bisa terima dan tidak bisa kita kerjakan atau kita kerjakan kurang maksimal, karena memang kekurangan sumberdaya dan keteraturan lembaga. Itu menjadi kendala yang sangat besar untuk saat ini. Sebenarnya begini kalau masalah administrasi itu diatur oleh dua atau tiga staff yang full time pasti bisa lebih baik. Karena kita tidak ada sumberdaya untuk kesana jadi dikerjakan dengan komitmen sukarela. Karena oleh orang-orang yang sambil kerja, orang-orang kalau ada masalah antara pekerjaan pribadi dengan kerjaan di JAKATARUB, lebih ke kerjaan pribadi. Jadi itu yang masih menjadi kendala besar sampai saat ini". 
Khazanah Sosial, Vol. 1 No. 1: 50-60

Gerakan Dialog Keagamaan Jaringan Kerja Antar Umat Beragama (Jakatarub) Dan Kontribusinya Terhadap

Kerukunan Hidup Umat Beragama

Dwi Wahyuni

\section{Kontribusi Gerakan Dialog Keagamaan Jakatarub Terhadap Kerukunan Hidup Umat Beragama di Kota Bandung}

Tiga indikator dalam kerukunan hidup umat beragama yaitu toleransi, kesetaraan, dan kerjasama.(Sari, 2017) Indikator toleransi merepresentasikan dimensi saling menerima dan menghargai perbedaan. Indikator kesetaraan mencerminkan keinginan saling melindungi, memberi hak dan kesempatan yang sama, tidak mengedepankan superioritas. Indikator kerjasama menggambarkan keterlibatan aktif bergabung dengan pihak lain. Memberikan empati dan simpati kepada kelompok lain dalam dimensi ekonomi, budaya, sosial dan keagamaan.

Arah peningkatan kerukunan hidup umat beragama tidak hanya pada toleransi saja. Karena sikap toleransi itu baru merupakan syarat awal kerukunan. Agar kerukunan antar umat beragama tumbuh dengan kuat, maka toleransi harus disertai dengan adanya kesetaraan antar umat beragama. Sikap kesetaraan juga harus diiringi dengan tindakan nyata dalam bentuk kerjasama di tengah kehidupan bermasyarakat. Dengan kerjasama yang tulus akan terbangun kepercayaan yang kuat agar dapat hidup berdampingan dengan damai, saling memajukan dan menguatkan. Tidak untuk saling menyakiti dan menyingkirkan.

Kontribusi gerakan dialog keagamaan JAKATARUB terhadap kerukunan hidup umat beragama di Kota Bandung dapat dipahami berdasarkan tiga indikator di atas. Sejak awal, JAKATARUB terus mengkampanyekan toleransi sebagai dasar untuk hidup damai dan rukun di Indonesia, khususnya di Kota Bandung. Toleransi di JAKATARUB tidak sebatas teori saja, rasa saling menerima dan menghargai perbedaan satu sama lain ditunjukkan dalam berbagai tindakkan. Sikap saling melindungi dan memberikan hak yang sama juga tetap ditunjukkan anggota dan pengurus JAKATARUB. Hal ini merupakan wujud nyata sebagai bukti bahwa di JAKATARUB kesetararan itu sangat penting dikedepankan. JAKATARUB menerima semua agama dan kenyakinan yang memiliki hak untuk hidup damai di Kota Bandung. Karena mereka juga warga negara yang berhak untuk mendapatkan perlindungan yang sama dengan lainnya. Tidak hanya agama yang diakui pemerintah, di JAKATARUB menerima dengan luas hati agama, sekte suatu agama dan kepercayaan yang ada di Kota Bandung seperti Ahmadiyah, Syiah, Baha'i, bahkan Ateisme sekalipun. Selain toleransi dan kesetaraan, di JAKATARUB sejak awal telah menyadari bahwa dibutuhkan kerjasama antar umat beragama untuk menghadapi berbagai persoalan kehidupan. Dalam kegiatan-kegiatannya, JAKATARUB menunjukkan saling berkerjasama satu sama lain, tanpa membedakan latar belakang keagamaan. Apa yang terjadi dalam dinamika komunitas JAKATARUB ini akan memberikan kontribusinya terhadap kerukunan hidup umat beragama di Kota Bandung.

JAKATARUB merupakan pelopor dan inspirasi dalam kegiatan lintas agama di kota Bandung. Kegiatan-kegiatan lintas iman, misalkan Bandung Lautan Damai (BALAD), awalnya kegiatan ini diinisiasi oleh Yunita, pengurus JAKATARUB. Yunita yang memiliki ide, selanjutnya didiskusikan di lingkungan JAKATARUB, dan setelahnya dilaksanakan dengan mitra-mitra JAKATARUB. Kegiatan BALAD merupakan kegiatan skala besar yang melibatkan berbagai mitra, dilaksanakan setiap tahun untuk memperingati Hari Toleransi Internasional. Tahun pertama pelaksanaan BALAD hanya dilaksanakan satu hari. Di tahuntahun selanjutnya, kegiatan BALAD ini dilaksanakan dengan rangkaian kegiatan yang terdiri dari beberapa kegiatan, bisa sampai 8 kegiatan. Dampak dari kegiatan BALAD ini sangat luas, sebab kampanye toleransi yang dilakukan di segala level dan juga disosialisasikan ke berbagai media yang di miliki JAKATARUB dan mitra-mitranya.(Suwarno, 2016)

Selama ini JAKATARUB menjadi media untuk semua orang yang rindu akan kebersamaan dalam satu perjumpaan yang saling terkoneksi satu sama lain. Dengan perjumpaan yang terjadi berdampak akan 
Khazanah Sosial, Vol. 1 No. 1: 50-60

Gerakan Dialog Keagamaan Jaringan Kerja Antar Umat Beragama (Jakatarub) Dan Kontribusinya Terhadap

Kerukunan Hidup Umat Beragama

Dwi Wahyuni

berkurangnya kecurigaan antar umat beragama. Bila ada masalah keagamaan di suatu tempat misalkan, jaringan JAKATARUB sangat mudah untuk saling berkomunikasi, sehingga masalah yang ada dapat diselesaikan dengan cepat, tidak berlarut-larut menjadi masalah yang lebih besar. JAKATARUB telah mengupayakan sejauh yang bisa dilakukan dengan keterbatasan sumberdaya yang ada. JAKATARUB membuka ruang perjumpaan langsung antar umat beragama di Kota Bandung. Di sisi lain JAKATARUB juga mengadvokasi isu-isu kebebasan beragama bersama mitranya seperti LBH Bandung, SAPA Institute dan sebagainya. Kontribusi JAKATARUB secara khusus, misalkan saat ada swiping di berbagai gereja seperti GKI. Saat itu JAKATARUB datang dan membantu pengurus Gereja untuk advokasi kepada kelompok yang swiping. Sehingga saat itu, dari gereja merasa tidak menanggung masalah sendiri tapi ada orang-orang JAKATARUB yang punya andil dan membantu.(Rukmana, 2013)

Secara pesifik JAKATARUB bergerak di bidang edukasi publik, jadi JAKATARUB membuat aksi-aksi nyata mulai dari kampaye di Car Free Day terus membuat diskusi yang terbuka untuk umum, membuat diskusi dikelompok yang intensif, lalu membuat pendampingan terhadap peserta yang berlatar belakang agama yang berbeda di kegiatan Youth Interfaith Camp. JAKATARUB mendampingi anak-anak muda perwakilan dari kampus-kampus untuk bicara tentang toleransi dan wawasan kebangsaan. JAKATARUB juga membuat kurikulum khusus pelatihan toleransi untuk anak-anak muda dari tingkat dasar sampai tingkat menengahnya. JAKATARUB juga membuat media-media kreatif yang berbicra soal toleransi, mulai dari penerbitan buku sampai penerbitan kartu remi. Dua buku yag telah terbit, Dialog 100: 100 Kisah Persahabatan Lintas Iman dan 12 Kisah Perjalanan Menuju Damai; Melangkahi Luka, serta dengan pembuatan kartu Remi Perdamaian

Pada tahun 2017, JAKATARUB juga membuat video-video tentang keragaman beragama, lalu JAKATARUB mengelola media yang menjadi bagian penting untuk kegiatan-kegiatan komunitas di Kota Bandung. Media-media tersebut bebicara soal isu kemanusiaan, kebebasan beragama, kesetaraan dan sebagainya. Untuk sistus Website, Instagram, Facebook dan Youtube JAKATARUB, tidak hanya berisi kegiatan JAKATARUB saja, tapi selalu dikembangkan menjadi media bagi komunitas-komunitas lain.

Gerakan dialog keagamaan JAKATARUB telah memberikan kontribusi besar terhadap kerukunan hidup umat beragama di Kota Bandung.(Banawiratma, J.B, 2010) Upaya JAKATARUB untuk menerima semua kelompok keagamaan telah membentuk perjumpaan setiap umat beragama. Dengan perjumpaanperjumpaan yang ada membuat umat beragama di Kota Bandung bisa saling menghargai dan menerima perbedaan satu sama lain. Tidak sekedar menerima dan menghargai, bahkan dengan berbagai latar belakang agama dan kenyakinan yang berbeda, di JAKATARUB tetap bisa berkerjasama dalam berbagai bidang. Usaha-usaha JAKATARUB dalam melakukan pendampingan terhadap kelompok-kelompok yang diperlakukan diskriminatif juga telah mampu menghadirkan suasana cair. Sehingga penyelesaian masalah tidak dilakukan dengan kekerasan namun diselesaikan dengan dialog dan perundingan yang baik. Dalam upaya terhadap edukasi publik yang dilakukan JAKATARUB, telah berdampak keterbukaan masyarakat terhadap isu-isu kemanusian, toleransi, kesetaran dan sebagainya. Pentingnya bertoleransi dan berkerjasama antar umat beragama, telah disampaikan kepada masyarakat secara luas dan kepada anak muda yang akan melanjutkan kehidupan dimasa depan yang lebih damai dan harmonis.

\section{SIMPULAN}

Pada dasarnya proses diskusi yang dilakukan di Lakpesdam PCNU kota Tasikmalaya berlangsung secara demokratis, argumentatif, membahas permasalahan Islam kontemporer yang aktual dan faktual, serta bertujuan untuk menambah pengetahuan dan menumbuhkan rasa toleransi dengan tidak melahirkan keputusan dan kesepakatan yang bersifat mengikat, karena hakikatnya akan diberikan 
Khazanah Sosial, Vol. 1 No. 1: 50-60

Gerakan Dialog Keagamaan Jaringan Kerja Antar Umat Beragama (Jakatarub) Dan Kontribusinya Terhadap

Kerukunan Hidup Umat Beragama

Dwi Wahyuni

otoritas kepada peserta diskusi. Dalam posisi seperti itu, maka hakikat dari diskusi sebagai metode dakwah yang dikembangkan oleh Lakpesdam PCNU kota Tasikmalaya, lebih sebagai proses mengeksplorasi pengetahuan, sosialisasi ilmu, internalisasi penghayatan dan pemahaman isu-isu keagamaan kontemporer, yang tetap menjaga bingkai-bingkai perbedaan atau ikhtilaf diantara peserta diskusi.

Oleh karena itu, kegiatan diskusi sebagai metode dakwah yang dilakukan oleh Lakpesdam PCNU kota Tasikmalaya, dapat menjadi model alternatif dakwah dalam pengembangan keilmuan. Metode diskusi ini pada hakikatnya dapat digunakan dalam koridor sebagai proses untuk mengeksplorasi pengetahuan, sosialisasi ilmu, internalisasi penghayatan dan pemahaman isu-isu keagamaan kontemporer, yang tetap menjaga bingkai-bingkai perbedaan atau ikhtilaf diantara peserta diskusi. Sebab jika kegiatan diskusi berusaha menggiring para peserta diskusi untuk menyepakati satu kesepakatan saja, tanpa menampung keragaman pendapat dari para peserta diskusi, maka kegiatan tersebut bukan merupakan kegiatan diskusi, serta tidak akan efektif dijadikan sebagai metode dakwah.

Kegiatan diskusi sebagai metode dakwah pada hakikatnya menuntut para peserta diskusi untuk bersikap toleransi, dengan cara menghargai perbedaan pendapata di antara seluruh peserta diskusi. Oleh karena itu, sudah sepantasnya kegiatan diskusi berjalan secara demokratis tanpa adanya interfensi dari pihak-pihak tertentu.

\section{DAFTAR PUSTAKA}

Banawiratma, J.B, D. (2010). Dialog Antarumat Beragama; Gagasan Dan Praktik Di Indonesia. Jakarta: Mizan Publika.

Farida, A. (2015). Manajemen Konflik Keagamaan Melalui Jaringan Kerja Antar Umat Beragama Di Bandung Jawa Barat. Jurnal Al-Qalam, 21(1).

Febriani, L. (2017). Mobilisasi Sumberdaya dalam Gerakan Literasi (Studi pada Gerakan Vespa Pusaka). Jurnal Society, 5(1).

Hemawati, R. (2016). Toleransi Antar Umat Beragama di Kota Bandung. Jurnal UMBARA, 1(2).

Rukmana, A. (2013). Islam dan Dialog Antar Agama di Indonesia: dari Dialog Teologis Menuju Dialog Antropollogis. Jurnal Bimas Islam, 6(3).

Sari, D. K. (2017). Strategi Mobilisasi Gerakan Masyarakat dalam Menutup Industri Pengelolahan Limbah

B3 di Desa Lakardowo Kabupaten Mojokerto. Jurnal Politik Indonesia, 2(1).

Silalahi, U. (2010). Metode Penelitian Sosial. Bandung: Refika Aditama.

Sugiyono. (2013). Memahami Penelitian Kualitatif. Bandung: CV. Alfabeta.

Sukmana. (2016). Konsep dan Teori Gerakan Sosial. Malang: Intrans Publishing.

Suwarno, J. (2016). Gerakan Muncar Rumahku dan Strategi Mobilisasi Sumber Daya pada Gerakan Sosial Penyelamat Lingkungan. Jurnal Pemikiran Sosiologi, 3(2).

Umar, N. (2013). Interfaith Dialog dalam Mengmbangkan Kehidupan beragama yang Harmoni dan Damai. Jurnal Bimas Islam, 6(3).

Wahyuni, D. (2016). Nilai-Nilai Dasar Perjuangan HMI: Suatu Ikhtiar Mewujudkan Kerukunan Hidup Umat Beragama di Indonesia. Jurnal Ilmu Agama, 17(2). 